\title{
Preface and introduction
}

Viewed in the context of business and management, creativity is the ability to bring about ideas and knowledge that have specific impacts on corporate activities not only to upgrade and improve products, but also to realize new product developments and build new business processes and business models, etc. (e.g., Amabile, 1983). The creativity of people and groups is an important research theme for generating ideas for new products and businesses, and attempts at exploration and exploitation of it have advanced around the world both in academic research (social psychology, I/O psychology, cognitive psychology, business administration, science and technology, education, linguistics, arts and social engineering, etc.) and practical application fields (creativity engineering, design engineering, etc.). To date, this is a theme for which much literature (from academic research through to practical documentation) has accumulated.

It has long been identified in academic research that creativity is difficult to clearly define because it entails complex concepts that combine various intellectual abilities (Sternberg and Lubart, 1996). What can be agreed upon to some extent in psychological research is a definition of creativity as "the abilities to create new and useful things" (e.g., Sternberg and Lubart, 1999; Runco and Jaeger, 2012). As abilities, creativity includes not only the ability to bring about more good ideas, but also the generational ability to achieve products and services from such ideas. Much research on creativity at the personal, team and organizational levels has also been accumulated in I/O psychology (e.g., Mumford et al., 2012; Reiter-Palmon et al., 1997; Reiter-Palmon, 2018a).

In business studies and psychology to date, the importance of "intrinsic motivation" has been identified as a factor in raising creativity (e.g., Amabile, 1988, 1995; Elsbach and Hargadon, 2006). It has been clearly identified that intrinsic motivation raises personal interests, curiosity and the desire to learn as well as knowledge flexibility and sustainability, and hence raises creativity (Ryan and Deci, 2000; Shalley et al., 2004). Amabile (1996) suggests that psychological effects come into play when novelty as ideas that have come about through intrinsic motivation shift to utility (usefulness) as the later subsequent stage. Crucially in this perspective, creativity is both "novelty" and "utility", and achieves new objects or events that broadly impact society (in other words innovation).

From existing research on creativity and innovation, the importance of not only intrinsic motivation of individuals (e.g., Frese et al., 1997; Mumford, 2012; Mumford and Hemlin, 2017) but also its expansion to the levels of teams and entire organizations has been identified (e.g., Hemlin et al., 2004; Kodama, 2007a, 2009b, 2014; Mumford, 2012; Sternberg, 1999; Tidd and Bessant, 2013). Generating creativity and innovation in organizations entails mutual linking of the organizational and personal levels. This results in many cases in which innovation processes occur in teams as projects (e.g., Kodama, 2007b; Reiter-Palmon, 2018b). 
Also, from the perspective of knowledge creation theory (Nonaka and Takeuchi, 1995; Nonaka et al., 2014), creativity is also the capability to contribute to society by bringing about businesses with high ethical standards and new value by converging and converting the various knowledge and specializations of the human resources working in corporations, etc. Knowledge creation theory is not the same as organizational learning theory (e.g., Huber, 1991). In contrast to learning, creativity entails producing something that hasn't existed in the past, although it doesn't mean that something is born from nothing. Creativity also means creating new combinations of diverse knowledge such as that of existing objects or events. In terms of cognitive science, creativity is the process of newly linking existing and dissimilar knowledge networks, as opposed to learning, which is the process of enriching networks by incorporating new information into existing knowledge networks (Nonaka and Takeuchi, 1995; Kodama, 2009a, b, 2014).

Although both learning and creativity enrich knowledge networks, the processes to arrive at such an enriched state are not the same. Learning involves the provision from the outside of information that forms new relationships, whereas creativity spontaneously occurs at the personal or group level (in which the aforementioned intrinsic motivation is a factor). Thus, while learning comes from externalities such as teachers or teaching materials, creativity is rooted in spontaneous searching and new combinations for self-fulfillment by humans themselves. Although the triggers for creative processes come from the outside, the processes of discovery of solutions are spontaneous and generative. Knowledge creation theory emphasizes tacit knowledge that is both subjective and physical as an internal source of will and commitment (Nonaka and Takeuchi, 1995).

Such processes of forming new links between dissimilar networks have a significant relationship with creativity. In his insightful work "The Act of Creation" (Koestler, 1964), Arthur Koestler (a Hungarian-born thinker, writer and journalist) describes concepts about the creative process. Koestler devoted himself to clarifying human creativity, and provided significant knowledge on the subject. A representative example is the concept of "bisociation" (his coinage) central to Koestler's theory of creativity. Bisociation is the recognition of common conditions, theories or concepts in frameworks of two or more dissimilar recognitions (or pieces of knowledge) that have respective uniformities, and that have been stylized traditionally and historically as having no association with each other - conflicts between such dual or multiple frames of reference (matrices) are overcome, and dialectically fused and integrated in a new dimension. Koestler asserted that this bisociation was the essence of creativity.

In other words, creative ideas are born when two dissimilar concepts collide and two ideas that would at first glance seem unrelated are combined (converged and integrated). For example, this suggests the importance of thinking on two or more different straight lines or planes instead of thinking with existing (or path-dependent) methods of thinking with a single line or a two-dimensional plane. In practice, ideas rich in creativity have often emerged in cases in which previously unrelated ideas and things have been linked by independent methods.

For example, abilities such as the auditory ability in music, motor sense ability in dance, design ability in mechanical engineering or mathematical ability in physics dominate the activities of those different disciplines while using intellectual abilities from other fields at the same time (Robinson, 2017). Even in traditional psychology research, it has been reported that the more different the elements of new combinations, in other words the more dissimilar the concepts, the more creative the processes and their results (Mednick, 1962). 
Koestler found that bisociation in the intellectual activities of humans and higher primates entails advanced intelligence functioning in a different dimension to the processes of ordinary object recognition and thinking with language, or the generally assumed (e.g., in experiments with mice) problem solving through trial and error. For example, this was demonstrated in experiments once conducted on a smart chimpanzee by Wolfgang Köhler, one of the founders of Gestalt psychology. Koestler (1981) further notes that such creative originality is ubiquitous not only in the minds of those with good humor, artists and scientists, but also in developmental processes in all kinds of evolution.

In recent years, the concept of bisociation has spread to human resource development in product development training and employee training in companies, etc. This book aims to pursue the theory and mechanism of creativity development and knowledge convergence (Kodama, 2014) with a view to nurturing creative human resources that will bring about innovation and hence greatly contribute to society in all fields and industries.

This book presents two concepts related to Koestler's bisociation concept, as a method of thinking to bring about innovative ideas. One is the concept of "boundaries vision", which entails the idea that as boundary vision increases, the ability to "see what cannot be seen" arises and results in innovative capability. The other concept is that of "boundaries knowledge (knowing)". This entails the idea that new value, products and services can be brought about by combining dissimilar objects and events through the creation of boundaries knowledge. This book shows that the concepts that express the concept of "bisociation" are those of boundaries vision and boundaries knowledge.

For example, there is a mobile phone (e.g., a smartphone) game to connect two different concepts that is now widely used worldwide. Twenty years ago, playing games on a mobile phone was unthinkable. iPhone's optical image stabilization function was introduced in Brian Merchant's “THE ONE DEVICE" (Merchant, 2017). This function was invented by Mitsuaki Oshima of the Japanese company Panasonic. This invention measures the rotational angle of the video camera with a vibrating gyroscope often used in car navigation systems to correct the image and eliminate camera shake. Oshima (2010) asserts that innovation is creating a new network that connects different ideas.

The book also discusses in detail case studies of new technologies, products and services that have been born through the convergence of the mobile phone with something else, for example the merging of cameras and mobile phones to produce the mobile phone with built-in camera (currently smartphones); devices which have greatly impacted on our leisure and daily living environments. Having become infused into our enjoyment of life, these can also be called groundbreaking innovations brought about by boundaries vision and boundaries knowledge (knowing).

The purpose of this book is to apply the concepts of boundaries vision and boundaries knowledge in the field of business and management both theoretically and practically. Specifically, while focusing on literature on strategy theory (in particular dynamic capabilities) and knowledge creation theory, the book presents a theoretical framework about how the concepts of boundaries vision and boundaries knowledge, which exist in the background of the concept of bisociation, can be applied to dynamic capabilities and knowledge creation. Then, the book observes and discusses the dynamic mechanisms of boundaries vision and boundaries knowledge through in-depth case studies. 


\section{REFERENCES}

Amabile, T. M. (1983). Brilliant but cruel: Perceptions of negative evaluators. Journal of Experimental Social Psychology, 19(2), 146-156.

Amabile, T. M. (1988). A model of creativity and innovation in organizations. Research in Organizational Behavior, 10(1), 123-167.

Amabile, T. M. (1995). Attributions of creativity: What are the consequences? Creativity Research Journal, 8(4), 423-426.

Amabile, T. M. (1996). Creativity in Context: Update to the Social Psychology of Creativity. Boulder, CO: Westview Press.

Elsbach, K. D., \& Hargadon, A. B. (2006). Enhancing creativity through "mindless" work: A framework of workday design. Organization Science, 17(4), 470-483.

Frese, M., Fay, D., Hilburger, T., Leng, K., \& Tag, A. (1997). The concept of personal initiative: Operationalization, reliability and validity in two German samples. Journal of Occupational and Organizational Psychology, 70, 139-161.

Hemlin, S., Allwood, C. M., \& Martin, B. R. (Eds) (2004). Creative Knowledge Environments:The Influences on Creativity in Research and Innovation. Cheltenham, UK and Northampton, MA, USA: Edward Elgar Publishing.

Huber, G. P. (1991). Organizational learning: The contributing processes and the literatures. Organization Science, 2(1), 88-115.

Kodama, M. (2007a). The Strategic Community-Based Firm. London, UK: Palgrave Macmillan.

Kodama, M. (2007b). Knowledge Innovation: Strategic Management as Practice. Cheltenham, UK and Northampton, MA, USA: Edward Elgar Publishing.

Kodama, M. (2009a). Boundaries innovation and knowledge integration in the Japanese firm. Long Range Planning, 42(4), 463-494.

Kodama, M. (2009b). Innovation Networks in Knowledge-Based Firms: Developing ICT-Based Integrative Competences. Cheltenham, UK and Northampton, MA, USA: Edward Elgar Publishing.

Kodama, M. (2014). Winning Through Boundaries Innovation: Communities of Boundaries Generate Convergence. Oxford, UK: Peter Lang.

Koestler, A. (1964). The Act of Creation. New York: Penguin Books.

Koestler, A. (1981). The three domains of creativity. In The Concept of Creativity in Science and Art (pp. 1-17). Dordrecht: Springer.

Mednick, S. (1962). The associative basis of the creative process. Psychological Review, 69(3), 220-232.

Merchant, S. (2017). The promise of creative/participatory mapping practices for sport and leisure research. Leisure Studies, 36(2), 182-191.

Mumford, M. D. (Ed.) (2012). Handbook of Organizational Creativity. London: Academic Press.

Mumford, M. D., \& Hemlin, S. (Eds) (2017). Handbook of Research on Leadership and Creativity. Cheltenham, UK and Northampton, MA, USA: Edward Elgar Publishing.

Mumford, M. D., Hester, K. S., \& Robledo, I. C. (2012). Creativity in organizations: Importance and approaches. In Handbook of Organizational Creativity (pp. 3-16). London: Academic Press.

Nonaka, I., \& Takeuchi, H. (1995). The Knowledge-Creating Company. New York, NY: Oxford University Press.

Nonaka, I., Kodama, M., Hirose, A., \& Kohlbacher, F. (2014). Dynamic fractal organizations for promoting knowledge-based transformation: A new paradigm for organizational theory. European Management Journal, 32(1), 137-146.

Oshima, M. (2010). How to Bring Up Your Inspiration (in Japanese), Tokyo, Japan: Aki Shobou.

Reiter-Palmon, R. (2018a). Are the outcomes of creativity always positive? Creativity: TheoriesResearch-Applications, 5(2), 177-181.

Reiter-Palmon, R. (Ed.) (2018b). Team Creativity and Innovation. New York, NY: Oxford University Press.

Reiter-Palmon, R., Mumford, M. D., O’Connor Boes, J., \& Runco, M. A. (1997). Problem construction and creativity: The role of ability, cue consistency, and active processing. Creativity Research Journal, 10(1), 9-23.

Robinson, J. (2017). Economic Philosophy. Abingdon: Routledge. 
Runco, M. A., \& Jaeger, G. J. (2012). The standard definition of creativity. Creativity Research Journal, 24(1), 92-96.

Ryan, R. M., \& Deci, E. L. (2000). Intrinsic and extrinsic motivations: Classic definitions and new directions. Contemporary Educational Psychology, 25(1), 54-67.

Shalley, C. E., Zhou, J., \& Oldham, G. R. (2004). The effects of personal and contextual characteristics on creativity: Where should we go from here? Journal of Management, 30(6), 933-958.

Sternberg, R. J. (Ed.) (1999). Handbook of Creativity. Cambridge, UK: Cambridge University Press.

Sternberg, R. J., \& Lubart, T. I. (1996). Investing in creativity. American Psychologist, 51(7), 677-688.

Sternberg, R. J., \& Lubart, T. I. (1999). The concept of creativity: Prospects and paradigms. In R. J. Sternberg (Ed.), Handbook of Creativity, (pp. 3-15). Cambridge, UK: Cambridge University Press.

Tidd, J., \& Bessant, J. (2013). Managing Innovation: Integrating Technological, Market and Organizational Change. 5th ed. London: John Wiley \& Sons. 